\title{
TWO TRIGONOMETRIC INTEGRAL INEQUALITIES
}

\author{
YI ZHAO \\ Abstract. The present paper establishes some important trigonometric integral inequalities re- \\ lated to functions of mean value bounded variation in real sense. \\ Mathematics subject classification (2010): 42A05, 42A38. \\ Keywords and phrases: Sine integral, trigonometric integral inequality, mean value bounded variation.
}

\section{REFERENCES}

[1] L. FenG, V. TOTIK AND S. P. ZHOU, Trigonometric series with a generalized monotonicity condition, Acta. Math. Sinica, English Ser., 30, 8 (2014), 1289-1296.

[2] L. Feng And S. P. Zhou, Trigonometric inequalities in the MVBV condition, Math. Ineq. Appl., accepted.

[3] L. LEINDLER, On the uniform convergence and boundedness of a certain class of sine series, Anal. Math., 27, (2001), 279-285.

[4] S. A. TelyakovskiI, On partial sums of Fourier series of functions of bounded variation, Proc. Steklov. Inst. Math., 219, (1997), 372-381.

[5] M. Z. WANG AND Y. ZHAO, Generalization of some classical results under MVBV condition, Math. Ineq. Appl., 12, (2009), 433-440.

[6] Y. ZhaO, L. Feng AND S. P. ZHOU, The uniform convergence of sine integrals, to appear.

[7] S. P. ZHOU, An important application of mean value bounded variation concept in weighted integrability, to appear.

[8] S. P. ZHou, Monotonicity Condition of Trigonometric Series: Development and Application, Science Press, Beijing, 2012, in Chinese.

[9] S. P. ZHOU, P. ZHOU AND D. S. YU, Ultimate generalization to monotonicity for uniform convergence of trigonometric series, Science China Math., 53, (2010), 1853-1862, available: arXiv: math.CA/0611805 v127 Nov 2006. 